\section{Constructs of poor sleep quality in adolescents: associated factors}

\author{
Os construtos de baixa qualidade de sono em \\ adolescentes: fatores associados
}

\section{Constructos de calidad deficiente del sueño en adolescentes: factores asociados}

Lailah Maria Luiza Gonzaga Cavalcanti

Rodrigo Antunes Lima 2

Caroline ramos de Moura Silva 1

Mauro Virgilio Gomes de Barros 1

Fernanda Cunha Soares 1

doi: 10.1590/0102-311X00207420

\begin{abstract}
This study aims to evaluate factors associated with sleep quality (overall and by domains) in adolescents. A cross-sectional study. This study was conducted with 1,296 first-year high school students from public schools in the Northern Region of the State of Pernambuco, Brazil. Demographic, socioeconomic, and behavioral data were obtained with a questionnaire. Sleep quality was measured using the Pittsburgh Sleep Quality Index (PSQI) Body mass in$\operatorname{dex}(B M I)$ was calculated based on the ratio of weight and height squared. Multilevel linear and logistic regressions evaluated factors associated with sleep quality. We observed 53\% of adolescents reported poor sleep quality. Adolescents at higher risk of clinical depression were 3.45 times more likely to have poor sleep quality (95\%CI: 2.04; 5.81), and each additional unit in the social anxiety score presented 1.03 (95\% CI: 1.01; 1.05) higher odds of adolescents having poor sleep quality. Adolescents with depressive symptoms had higher sleep latency, greater sleep disturbance, and greater daytime sleep dysfunction. Social anxiety was associated with sleep latency, sleep disturbance, and daytime sleep dysfunction. Higher risk of clinical depression was associated with all domains related to sleep quality. Negative health perception was associated with sleep disturbance, and physical inactivity was associated with daytime sleep dysfunction. Social anxiety and especially higher risk of clinical depression were determinants of poor sleep quality. Changes in sleep latency, sleep disturbance and daytime sleep dysfunction seems to be relevant to poor sleep quality.
\end{abstract}

Sleep; Depression; Anxiety; Adolescent

\section{Correspondence}

F. C. Soares

Universidade de Pernambuco.

Av. Agamenon Magalhães s/n, Recife, PE 50100-010, Brasil. fercsoares@gmail.com

1 Universidade de Pernambuco, Recife, Brasil.

2 University of Graz, Graz, Austria. 


\section{Introduction}

Chronic sleep loss in adolescence has been widely reported in the literature and is considered a public health epidemic 1 . Poor sleep quality causes a general imbalance in the body, especially in the brain chemicals that regulate the sleep-wake cycle, consolidation of memory and body temperature regulation 1 . Poor sleep quality can result in poor quality of life, poor school performance 2 , and may even lead to suicidal ideation 3 . Lack of sleep-related physiological restoration may also result in higher levels of stress 4, mnemonic and attention deficits 5, as well as behavioral and emotional problems 6 .

Healthy People 2020 7, a science-based chronogram for improving Americans' health by the year 2020, states that the ideal sleep time during adolescence is at least eight or more hours of sleep a day. In Washington DC (United States), the prevalence of poor sleep quality in young people was $60 \% 8$, while $31 \%$ of Saudi adolescents slept less than seven hours/day 9 . Among Brazilian adolescents, $53.6 \%$ had a sleep duration of less than 8 hours on school days 10 .

Due to the consequences of poor sleep quality, the analysis of the determinants related to sleep during adolescence is significant in order to help design intervention studies aimed to improve the sleep quality of this population. As demonstrated in a meta-analysis, cognitive and behavioral interventions improved sleep quality in school-age children and adolescents 11 . Factors associated with poor sleep quality in adolescents are: having formal employment in addition to studying, concerns over good grades 12, socialization, depressive symptoms, lack of sports practice and other extracurricular activities, increased screen time 13 , unhealthy lifestyle 14 , and lack of parental monitoring or bedtime rules 15. More specifically, stressed, anxious, or depressed students are less likely to use adaptive coping strategies, which leads to decreased sleep quality or greater variability in sleep latency 16 . In contrast, optimism seems to be a predictor for good sleep quality 17 .

Despite some evidence regarding the determinants of poor sleep quality, it is not well-stablished which factors are associated with sleep quality domains such as latency, insufficiency, disturbance, daytime dysfunction, subjective quality, duration, and use of medication. Therefore, this study aims to evaluate factors associated with sleep quality (overall and by domains) in adolescents.

\section{Methods}

\section{Participants}

This is a cross-sectional study, part of a project designed to intervene in physical education classes to reduce sedentary behavior and improve cognitive functions - SACODE project (acronym for Health, Cognition and School Performance, in Portuguese), which started in 2017. In total, 1,474 first-year students from 11 public high school were eligible to participate in the study; these students dwelled in the area of Vale do Capibaribe in Pernambuco State, Brazil. In the baseline, 1,296 adolescents (572 boys and 724 girls) agreed to participate. SACODE project aimed to evaluate the effects on a multicomponent six-month intervention. Schools staff indicated adolescents who presented physical or cognitive limitations and were excluded from the study. The protocol was approved by the Human Ethics Research Committee of the University of Pernambuco (protocol n. 55741016.0.0000.5207). All parents were informed of the research by signing the Informed Consent Form and the adolescents by the Term of Assent.

\section{Measures}

Only variables included in this study will be detailed. Data was collected during March and April in 2017 (spring) by a trained group of researchers comprised of master's and PhD students and PhDs from the University of Pernambuco. 


\section{- Outcome}

Sleep quality was assessed by the Pittsburgh Sleep Quality Index (PSQI). This questionnaire consists of 19 individual items, subdivided in seven domains: D1 - subjective quality of sleep (good/bad); D2 sleep latency - time spent sleeping (numerical scale); D3 - sleep duration (six hours or more/less than six hours); D4 - usual sleep efficiency (numerical scale); D5 - sleep disturbance (numerical scale); D6 - use of sleeping medication (no/yes); D7 - daytime sleep dysfunction (numerical scale). The overall score was calculated 18, ranging from 0 to 21 points and the higher score, the poorer the sleep quality. Sleep quality was categorized into healthy sleep quality ( $0-4$ points) and poor sleep quality $(>5$ points). The PSQI has been validated for use in Brazilian adolescents 19.

\section{- Exposures}

Depressive symptoms were evaluated by The Center for Epidemiological Studies-Depression Scale (CESD). This scale only provides a measure of the depressive symptomatology 20 , not a diagnosis of depression. A score ranging from 0 to 60 was used, in which a higher score represents higher depressive symptomatology. Participants were classified as low clinical depression risk (0 to 23 points) and high clinical depression risk (> 23 points) 20,21. Validation studies have demonstrated that CES-D has a good construct and concurrent validity on clinical and self-report criteria, high reliability, and acceptable agreement with clinical ratings of depression 22. Moreover, CES-D questionnaire was validated for use in the Portuguese language 23.

The Social Anxiety Scale for Adolescents (SAS-A) was used to evaluate social anxiety. This questionnaire consists of 26 items 24 and a higher score represents higher social anxiety. A previous investigation validated the Portuguese version of this questionnaire 25 .

Anthropometric measures were performed with the adolescent wearing lightweight clothing and barefoot. Three measurements were taken for each adolescent and the mean was used as the final measure. Body mass was measured by calibrated digital scales and height was obtained by portable stadiometers fixed to the wall with an accuracy of $0.5 \mathrm{~cm}$. Body mass index (BMI) and body height were calculated by BMI in $\mathrm{kg} / \mathrm{m}^{2}$.

Adolescents who reported performing at least 60 minutes per day of moderate to vigorous physical activity were considered physically active. Adolescents who considered their health as poor or regular were classified as having a poor health perception, while those who considered their health as good or excellent were classified as having a good health perception.

\section{- Covariables}

A questionnaire was used to obtain information on sex (boys, girls), age and maternal education level ( $\leq$ 8 years of education, $>8$ years of education), which was used as a measure of socioeconomical status 26 .

\section{Statistical analyses}

All statistical analyses were conducted in Stata 13 for Windows (https://www.stata.com). Mean, standard deviation and frequency distribution were the procedures adopted to describe numerical and categorical variables, respectively. Multilevel regressions were used to verify the association between depressive symptoms, anxiety, health perception, physical activity, BMI, and sleep quality dimensions: multilevel linear regression was used for sleep latency, usual sleep efficiency, sleep disturbance, and daytime sleep dysfunction; multilevel logistic regression for subjective sleep quality, sleep duration, and use of sleeping medication. In assessing the association of the independent variables listed above with total sleep quality, logistic multilevel regression was also used. None of the associations evaluated were moderated by the sex or the maternal education of the participants. Therefore, analysis are presented for the entire group of participants. All final models were adjusted for gender, age, and maternal education level. In the multilevel regression models, cluster-related variance (school and classrooms) and intraclass correlation coefficient (ICC) were calculated. In the adjusted models the school and class ICCs were below $5 \%$. 


\section{Results}

The average age of the 1,296 adolescents (44\% male) evaluated was $15.02( \pm 1.05)$ years, with $29.87 \%$ being aged 13 or 14 years, three individuals aged 20 years and one aged 25 years. More than half of the students' mothers (53\%) attended school for less than eight years, $77 \%$ of the students reported positive health perceptions, and $37 \%$ of the adolescents referred to themselves as physically active. When assessing the adolescents' mental health, $24 \%$ of them had a higher risk of clinical depression, while social anxiety had a mean score of $40.6( \pm 11.6)$ points (Table 1$)$. The prevalence of poor overall sleep quality was $53 \%$. When analyzing the PSQI domains, $12 \%$ of adolescents had poor sleep quality, $35 \%$ slept less than seven hours a night, and 7.4\% ingested sleeping medication (Table 1).

Table 1

Socioeconomic and behavioral characteristics of adolescents in the first year of high school.

\begin{tabular}{|c|c|}
\hline Characteristics/Category & n (\%) \\
\hline \multicolumn{2}{|l|}{ Sex } \\
\hline Boys & $572(44.14)$ \\
\hline Girls & $724(55.86)$ \\
\hline \multicolumn{2}{|l|}{ Maternal educations level (years) } \\
\hline$<8$ & $608(52.60)$ \\
\hline$\geq 8$ & $548(47.40)$ \\
\hline \multicolumn{2}{|l|}{ Health perception } \\
\hline Good & 997 (76.99) \\
\hline Bad & $298(23.01)$ \\
\hline \multicolumn{2}{|l|}{ Clinical depression risk } \\
\hline Low & $939(76.22)$ \\
\hline High & $293(23.78)$ \\
\hline \multicolumn{2}{|l|}{ Insufficiently active } \\
\hline No & $478(37.00)$ \\
\hline Yes & $814(63.00)$ \\
\hline \multicolumn{2}{|l|}{ Quality of sleep - overall } \\
\hline Good & $339(46.89)$ \\
\hline Bad & $384(53.11)$ \\
\hline \multicolumn{2}{|l|}{ Domain 1 - quality of sleep } \\
\hline Good & $1134(87.90)$ \\
\hline Bad & $156(12.10)$ \\
\hline \multicolumn{2}{|l|}{ Domain 3 - time of sleep (hours) } \\
\hline$\geq 6$ & $960(87.91)$ \\
\hline$<6$ & $132(12.09)$ \\
\hline \multicolumn{2}{|l|}{ Domain 6 - medication for sleep } \\
\hline No & $1,196(92.36)$ \\
\hline Yes & $99(7.64)$ \\
\hline Age [mean (SD)] & $15.02( \pm 1.05)$ \\
\hline Anxiety [mean (SD)] & $40.68( \pm 11.64)$ \\
\hline BMI [mean (SD)] & $21.45( \pm 4.65)$ \\
\hline Domain 2 - sleep latency [mean (SD)] & $1.12( \pm 0.82)$ \\
\hline Domain 4 - usual sleep efficiency [mean (SD)] & $0.73( \pm 0.39)$ \\
\hline Domain 5 - sleep disturbance [mean (SD)] & $1.14( \pm 0.54)$ \\
\hline Domain 7 - daytime sleep dysfunction [mean (SD)] & $1.27( \pm 0.89)$ \\
\hline
\end{tabular}

BMI: body mass index; SD: standard deviation. 
Depressive symptoms and social anxiety were associated with poor overall sleep quality in adolescents. Adolescents at higher risk of clinical depression were 3 times more likely to have poor sleep quality $(\mathrm{OR}=3.45 ; 95 \% \mathrm{CI}$ : 2.04; 5.81) when compared to those at lower risk of clinical depression. Each unit of increase in the social anxiety score presents 1.03 (95\%CI: $1.01 ; 1.05)$ times more chance for adolescents to have poor sleep quality (Table 2).

Adolescents at higher risk of clinical depression had higher sleep latency $(\beta=0.33$; 95\%CI: 0.20; $0.46)$, more sleep disturbances $(\beta=0.33$; 95\%CI: 0.23 ; 0.43), and more daytime sleep dysfunction $(\beta=$ 0.46 ; $95 \%$ CI: 0.33 ; 0.59). Social anxiety was associated with sleep latency, i.e., longer time to sleep $(\beta=$ 0.01; 95\%CI: 0.01; 0.01), sleep disturbances ( $\beta=0.01$; 95\%CI: 0.01; 0.01), and daytime sleep dysfunction ( $\beta=0.01 ; 95 \% \mathrm{CI}$ : $0.00 ; 0.01)$. Poor health perception was associated with sleep disturbances $(\beta=$ 0.02; 95\%CI: $0.11 ; 0.81)$ and being insufficiently active was associated with daytime sleep dysfunction $(\beta=0.17$; 95\%CI: 0.06; 0.28) (Table 3).

Table 2

Multilevel logistic regression of factors associated with poor sleep quality in adolescents in the first year of high school.

\begin{tabular}{|c|c|c|}
\hline Characteristic & $\begin{array}{l}\text { Crude regression } \\
\text { OR }(95 \% \mathrm{Cl})\end{array}$ & $\begin{array}{c}\text { Adjusted regression * } \\
\text { OR }(95 \% \mathrm{Cl})\end{array}$ \\
\hline High clinical depression risk & $5.62(3.45 ; 9.14)$ & $3.45(2.04 ; 5.81)$ \\
\hline Anxiety & $1.04(1.03 ; 1.06)$ & $1.03(1.01 ; 1.05)$ \\
\hline Negative health perception & $1.47(0.99 ; 2.17)$ & - \\
\hline Insufficiently active & $1.54(1.11 ; 2.14)$ & $1.19(0.79 ; 1.77)$ \\
\hline BMI & $0.99(0.95 ; 1.03)$ & - \\
\hline
\end{tabular}

95\% Cl: 95\% confidence interval; BMI: body mass index; OR: odds ratio.

* Adjusted by sex, age and maternal education level.

\section{Table 3}

Multilevel linear regression of factors associated with different domains (sleep latency, sleep inefficiency, sleep disturbance and daytime sleep dysfunction) that make up sleep quality in adolescents.

\begin{tabular}{|c|c|c|c|c|c|c|c|c|}
\hline \multirow[t]{2}{*}{ Characteristic } & \multicolumn{2}{|c|}{ Sleep latency } & \multicolumn{2}{|c|}{ Sleep inefficiency } & \multicolumn{2}{|c|}{ Sleep disturbance } & \multicolumn{2}{|c|}{ Daytime sleep dysfunction } \\
\hline & $\begin{array}{c}\text { Crude } \\
\text { model } \\
\beta \\
(95 \% \mathrm{Cl})\end{array}$ & $\begin{array}{c}\text { Adjusted } \\
\text { model * } \\
\beta \\
(95 \% \mathrm{Cl})\end{array}$ & $\begin{array}{c}\text { Crude } \\
\text { model * } \\
\beta \\
(95 \% \mathrm{Cl})\end{array}$ & $\begin{array}{c}\text { Adjusted } \\
\text { model * } \\
\beta \\
(95 \% \mathrm{Cl})\end{array}$ & $\begin{array}{c}\text { Crude } \\
\text { model } \\
\beta \\
(95 \% \mathrm{Cl})\end{array}$ & $\begin{array}{c}\text { Adjusted } \\
\text { model * } \\
\beta \\
(95 \% \mathrm{Cl})\end{array}$ & $\begin{array}{c}\text { Crude } \\
\text { model } \\
\beta \\
(95 \% \mathrm{Cl})\end{array}$ & $\begin{array}{c}\text { Adjusted } \\
\text { model * } \\
\beta \\
(95 \% \mathrm{Cl})\end{array}$ \\
\hline $\begin{array}{l}\text { High clinical } \\
\text { depression risk }\end{array}$ & $\begin{array}{c}0.49 \\
(0.38 ; 0.60)\end{array}$ & $\begin{array}{c}0.33 \\
(0.20 ; 0.46)\end{array}$ & $\begin{array}{c}0.03 \\
(-0.03 ; 0.09)\end{array}$ & & $\begin{array}{c}0.47 \\
(0.38 ; 0.56)\end{array}$ & $\begin{array}{c}0.33 \\
(0.23 ; 0.43)\end{array}$ & $\begin{array}{c}0.66 \\
(0.55 ; 0.77)\end{array}$ & $\begin{array}{c}0.46 \\
(0.33 ; 0.59)\end{array}$ \\
\hline Anxiety & $\begin{array}{c}0.02 \\
(0.01 ; 0.02)\end{array}$ & $\begin{array}{c}0.01 \\
(0.01 ; 0.01)\end{array}$ & $\begin{array}{c}0.01 \\
(-0.01 ; 0.01)\end{array}$ & & $\begin{array}{c}0.02 \\
(0.01 ; 0.02)\end{array}$ & $\begin{array}{c}0.01 \\
(0.01 ; 0.01)\end{array}$ & $\begin{array}{c}0.02 \\
(0.01 ; 0.02)\end{array}$ & $\begin{array}{c}0.01 \\
(0.00 ; 0.01)\end{array}$ \\
\hline $\begin{array}{l}\text { Negative health } \\
\text { perception }\end{array}$ & $\begin{array}{c}0.22 \\
(0.11 ; 0.33)\end{array}$ & $\begin{array}{c}0.43 \\
(-0.08 ; 0.16)\end{array}$ & $\begin{array}{c}0.01 \\
(-0.05 ; 0.06)\end{array}$ & & $\begin{array}{c}0.15 \\
(0.06 ; 0.24)\end{array}$ & $\begin{array}{c}0.02 \\
(0.11 ; 0.81)\end{array}$ & $\begin{array}{c}0.26 \\
(0.15 ; 0.38)\end{array}$ & $\begin{array}{c}0.03 \\
(-0.09 ; 0.16)\end{array}$ \\
\hline $\begin{array}{l}\text { Insufficiently } \\
\text { active }\end{array}$ & $\begin{array}{c}0.09 \\
(-0.01 ; 0.18)\end{array}$ & & $\begin{array}{c}-0.02 \\
(-0.06 ; 0.03)\end{array}$ & & $\begin{array}{c}0.01 \\
(-0.07 ; 0.09)\end{array}$ & & $\begin{array}{c}0.32 \\
(0.22 ; 0.42)\end{array}$ & $\begin{array}{c}0.17 \\
(0.06 ; 0.28)\end{array}$ \\
\hline $\mathrm{BMI}$ & $\begin{array}{c}-0.01 \\
(-0.01 ; 0.01)\end{array}$ & & $\begin{array}{c}0.01 \\
(0.00 ; 0.01)\end{array}$ & $\begin{array}{c}0.01 \\
(-0.01 ; 0.01)\end{array}$ & $\begin{array}{c}0.01 \\
(-0.01 ; 0.01)\end{array}$ & & $\begin{array}{c}0.01 \\
(-0.01 ; 0.01)\end{array}$ & \\
\hline
\end{tabular}

95\% Cl: 95\% confidence interval; BMI: body mass index.

* Adjusted by sex, age, and maternal education level. 
These adolescents were also more likely to have subjective quality of poor sleep $(\mathrm{OR}=4.52$; 95\%CI: $2.87 ; 7.14)$, sleep duration less than 6 hours ( $\mathrm{OR}=2.93 ; 95 \% \mathrm{CI}: 1.82 ; 4.71)$, and greater chance of using sleeping medication $(\mathrm{OR}=2.95 ; 95 \% \mathrm{CI}: 1.69 ; 5.15)$ (Table 4$)$.

Table 4

Multilevel logistic regression between depressive symptoms, anxiety, health perception, physical activity and body mass index (BMI) and sleep problems in different domains (subjective sleep quality [poor], sleep duration [ 6 hours], use of sleeping medication [yes]) in adolescents.

\begin{tabular}{|c|c|c|c|c|c|c|}
\hline \multirow[t]{2}{*}{ Characteristic } & \multicolumn{2}{|c|}{ Subjective quality of sleep } & \multicolumn{2}{|c|}{ Sleep duration } & \multicolumn{2}{|c|}{ Use of sleeping medication } \\
\hline & $\begin{array}{c}\text { Crude } \\
\text { model } \\
\text { OR } \\
(95 \% \mathrm{Cl})\end{array}$ & $\begin{array}{c}\text { Adjusted } \\
\text { model * } \\
\text { OR } \\
(95 \% \mathrm{Cl})\end{array}$ & $\begin{array}{c}\text { Crude } \\
\text { model } \\
\text { OR } \\
(95 \% \mathrm{Cl})\end{array}$ & $\begin{array}{c}\text { Adjusted } \\
\text { model * } \\
\text { OR } \\
(95 \% \mathrm{Cl})\end{array}$ & $\begin{array}{c}\text { Crude } \\
\text { model } \\
\text { OR } \\
(95 \% \mathrm{Cl})\end{array}$ & $\begin{array}{c}\text { Adjusted } \\
\text { model * } \\
\text { OR } \\
(95 \% \mathrm{Cl})\end{array}$ \\
\hline High clinical depression risk & $\begin{array}{c}5.64 \\
(3.85 ; 8.28)\end{array}$ & $\begin{array}{c}4.52 \\
(2.87 ; 7.14)\end{array}$ & $\begin{array}{c}2.62 \\
(1.72 ; 4.00)\end{array}$ & $\begin{array}{c}2.93 \\
(1.82 ; 4.71)\end{array}$ & $\begin{array}{c}3.94 \\
(2.48 ; 6.25)\end{array}$ & $\begin{array}{c}2.95 \\
(1.69 ; 5.15)\end{array}$ \\
\hline Anxiety & $\begin{array}{c}1.04 \\
(1.03 ; 1.06)\end{array}$ & $\begin{array}{c}1.02 \\
(0.99 ; 1.03)\end{array}$ & $\begin{array}{c}1.01 \\
(0.99 ; 1.02)\end{array}$ & & $\begin{array}{c}1.04 \\
(1.02 ; 1.05)\end{array}$ & $\begin{array}{c}1.02 \\
(0.99 ; 1.04)\end{array}$ \\
\hline Negative health perception & $\begin{array}{c}2.52 \\
(1.74-3.66)\end{array}$ & $\begin{array}{c}1.43 \\
(0.91 ; 2.23)\end{array}$ & $\begin{array}{c}1.19 \\
(0.76 ; 1.86)\end{array}$ & & $\begin{array}{c}2.62 \\
(1.68 ; 4.07)\end{array}$ & $\begin{array}{c}1.65 \\
(0.97 ; 2.83)\end{array}$ \\
\hline Insufficiently active & $\begin{array}{c}1.35 \\
(0.92 ; 1.97)\end{array}$ & & $\begin{array}{c}0.80 \\
(0.54 ; 1.20)\end{array}$ & & $\begin{array}{c}1.28 \\
(0.82 ; 2.02)\end{array}$ & \\
\hline BMI & $\begin{array}{c}0.99 \\
(0.96 ; 1.03)\end{array}$ & & $\begin{array}{c}0.99 \\
(0.95 ; 1.04)\end{array}$ & & $\begin{array}{c}1.01 \\
(0.96 ; 1.05)\end{array}$ & \\
\hline
\end{tabular}

95\%Cl: 95\% confidence interval; BMI: body mass index; OR: odds ratio.

* Adjusted by sex, age and maternal education level.

\section{Discussion}

This study evaluated the association of health factors and sleep quality in adolescents in their first year of high school. As in other studies 27,28 , more than half of adolescents reported poor sleep quality. Higher risk of clinical depression and social anxiety were significant factors associated with poor sleep quality. Changes in sleep latency, sleep disturbance, and daytime sleep dysfunction seem relevant to poor sleep quality.

Higher risk of clinical depression was associated with poor sleep quality. In China, Guo et al. 29 observed sleep problems were more prevalent among adolescents with depressive symptoms. Higher risk of clinical depression was associated with all domains that constitute overall poor sleep quality. Depression scores correlate with functional brain connectivity, including the lateral orbitofrontal cortex (negative thoughts), cingulate cortex (recent memory), and precuneus (consciousness), resulting in overthinking situations and the consequences of negative emotional experience, which interferes with the sleep mechanism impairing its quality 30 . Furthermore, hormonal dysfunctions, which are characteristic of depression, can also alter the sleep-wake cycle, leading to circadian disturbance, sleep-wake irregularity, difficulty sleeping, and staying awake in accordance with the demands of the individual's environment, sometimes resulting in insomnia or drowsiness problems 31 .

The association between anxiety and poor sleep quality found in this sample supports findings from previous studies 32,33 . Anxiety, also called anticipatory stress, physiologically interferes with the hypothalamus-pituitary-adrenal axis, altering cortisol and cortisol upon awakening, in turn altering the individual's total sleep time ${ }^{34}$. In analyzing the behavioral factor, we can find social insecurity, family problems, or internet use, which increase anxiety and interfere with sleep latency, favoring sleep disorders such as insomnia that cause poor sleep quality 32,35 . 
In addition to being associated with total sleep quality, social anxiety and depressive symptoms were also associated with the domains of sleep latency, sleep disturbance, and daytime sleep dysfunction. Increased sleep latency may favor sleep disorders such as insomnia, causing daytime consequences such as fatigue, attention deficits and mood instability 36 . Possible hormonal dysfunctions caused by anxiety and depressive symptoms can alter the sleep-wake cycle, causing changes in sleep. According to the Sleep Institute, non-rapid eye moviment (NREM) sleep and rapid eye miviment (REM) sleep repeat every 70 to 110 minutes with 4 to 6 cycles per night, with the reported sleep changes suggesting that adolescents often woke up during the night, interrupting these cycles 37. Lying in bed has been reported as a coping and stress compensation mechanism, whereas daytime napping has been associated with increased mental stress, so it is plausible that mental disorders cause daytime fatigue, leading to increased daytime sleepiness in adolescents 38 . Sleep is a state of brain activity, and different mood states such as joy, sadness, and fear generate activating and inhibiting brain waves which cause changes in sleep quality 39 . Considering the above explanation, it is understandable that mental health indicators have been associated to more PSQI domains, in addition to being the only ones associated with overall sleep quality.

Regular physical activity was also associated with sleep quality in other studies 39,40. Physical activity generates a higher production of melatonin, a hormone linked to the circadian cycle responsible for sleep organization, so people who do physical activity have more consistent sleep and have less dysfunctions during the day such as naps 40 . Other studies also show that individuals who rate their own health as poor also rate their sleep quality as poor ${ }^{41}$. Some diseases may lead to sleep disorders as secondary causes such as depression or pain, or others may cause an increased incidence of sleep apnea and snoring triggered by obesity and metabolic syndrome 42 .

The findings of this study should be carefully observed given some of its limitations. The crosssectional design limits the possibility of determining whether poor sleep quality is a consequence of depressive symptoms and anxiety, or whether there is a mutual relationship between these variables. Nevertheless, we based our analysis on the prerogative that social anxiety and depressive symptoms may expose the adolescents to higher chance of poor sleep quality as supported by the literature 43 .

More than half of the adolescents suffer from poor sleep quality. Higher risk of clinical depression and social anxiety were important factors associated with poor sleep quality. Changes in sleep latency, sleep disturbance and daytime sleep dysfunction seem very relevant to poor sleep quality.

\section{Contributors}

L. M. L. G. Cavalcanti contributed to the acquisition, analysis and interpretation of data; also drafted and critically revised the manuscript. R. A. Lima, C. R. M. Silva and M. V. G. Barros contributed with design, data analysis and interpretation; also drafted and critically revised the manuscript. F. C. Soares contributed to the conception, design, data acquisition, analysis and interpretation; also drafted and critically revised the manuscript. All authors approved the final text and agreed to be responsible for all aspects of the work.

\section{Additional informations}

ORCID: Lailah Maria Luiza Gonzaga Cavalcanti (0000-0002-6029-2338); Rodrigo Antunes Lima (0000-0002-7778-2616); Caroline Ramos de Moura Silva (0000-0002-8727-0024); Mauro Virgilio Gomes de Barros (0000-0003-3165-0965); Fernanda Cunha Soares (0000-0001-6465-3164). 


\section{References}

1. Owens J. Insufficient sleep in adolescents and young adults: an update on causes and consequences. Pediatrics 2014; 134:e921-32.

2. Lanberg JM, Dvorky MR, Marshall S, Evans SW. Clinical implications of daytime sleepiness for the academic performance of middle school age adolescents with attention deficit hyperactivity disorder. J Sleep Res 2013; 22:542-8.

3. Chiu HY, Lee HC, Chen PY, Lai YF, Tu YK. Associations between sleep duration and suicidality in adolescents: a systematic review and dose-response meta-analysis. Sleep Med Rev 2018; 42:119-26.

4. Roberts RE, Ramsay Roberts C, Ger Chen I. Impact of insomnia on future functioning of adolescents. J Psychosom Res 2002; 53:561-9.

5. Steenari M-R, Vuontela V, Paavonen EJ, Carlson S, Fjallberg M, Aronen E. Working memory and sleep in 6- to 13-year-old schoolchildren. J Am Acad Child Adolesc Psychiatry 2003; 42:85-92.

6. Yen W-L, Shintani T, Nair U, Cao Y, Richardson $\mathrm{BC}$, Li Z, et al. The conserved oligomeric Golgi complex is involved in double-membrane vesicle formation during autophagy. J Cell Biol 2010; 188:101-14.

7. U.S. Department of Health and Human Services. Sleep health. https://www.healthypeo ple.gov/2020/topics-objectives/topic/sleephealth (accessed on 28/Mar/2020).

8. Adrian M, Charlesworth-Attie S, Vander Stoep A, McCauley E, Becker L. Health promotion behaviors in adolescents: prevalence and association with mental health status in a statewide sample. J Behav Health Serv Res 2014; 41:140-52.

9. Al-Hazzaa HM, Musaiger AO, Abahussain NA, Al-Sobayel HI, Qahwaji DM. Prevalence of short sleep duration and its association with obesity among adolescents 15- to 19-year olds: a cross-sectional study from three major cities in Saudi Arabia. Ann Thorac Med 2012; 7:133-9.

10. Pereira É, Felden G, Leite CR, Rebelatto CF, Andrade RD, Beltrame TS. Sleep in adolescents of different socioeconomic status: a systematic review. Rev Paul Pediatr 2015; 33:467-73.

11. Åslund L, Arnberg F, Kanstrup M, Lekander M. Cognitive and behavioral interventions to improve sleep in school-age children and adolescents: a systematic review and meta-analysis. J Clin Sleep Med 2018; 14:1937-47.

12. Arora T, Broglia E, Pushpakumar D, Lodhi T, Taheri S. An investigation into the strength of the association and agreement levels between subjective and objective sleep duration in adolescents. PLoS One 2013; 8:e72406.

13. Feng Q, Zhang Q, Du Y, Ye Y, He Q. Associations of physical activity, screen time with depression, anxiety and sleep quality among Chinese College freshmen. PLoS One 2014; 9:e100914.
14. Hitze B, Bosy-Westphal A, Bielfeldt F, Settler U, Plachta-Danielzik S, Pfeuffer M, et al. Determinants and impact of sleep duration in children and adolescents: data of the Kiel Obesity Prevention Study. Eur J Clin Nutr 2009; 63:739-46.

15. Randler C, Bilger S. Associations among sleep chronotype, parental monitoring, and pubertal development among German adolescents. J Psychol 2009; 143:509-20.

16. Tavernier R, Willoughby T. Are all eveningtypes doomed? Latent class analyses of perceived morningness-eveningness, sleep and psychosocial functioning among emerging adults. Chronobiol Int 2014; 31:232-42.

17. Lau EYY, Hui CH, Lam J, Cheung S-F. Sleep and optimism: a longitudinal study of bidirectional causal relationship and its mediating and moderating variables in a Chinese student sample. Chronobiol Int 2017; 34:360-72.

18. Buysse DJ, Reynolds CF, Monk TH, Berman SR, Kupfer DJ. The Pittsburgh Sleep Quality Index: a new instrument for psychiatric practice and research. Psychiatry Res 1989; 28:193-213.

19. Passos MHP, Silva HA, Pitangui ACR, Oliveira VMA, Lima AS, Araújo RC. Reliability and validity of the Brazilian version of the Pittsburgh Sleep Quality Index in adolescents. J Pediatr (Rio J.) 2017; 93:200-6.

20. Radloff L, Locke B. The CES-D scale: a SelfReport Depression Scale for research in the general population. Appl Psychol Meas 1977; 1:385-401.

21. Radloff L, Locke B. Handbook of psychiatric measures. Washington DC: American Psychiatric Association; 2000.

22. Roberts RE, Vernon SW. The Center for Epidemiologic Studies Depression Scale: its use in a community sample. Am J Psychiatry 1983; 140:41-6.

23. Carvalho C, Cunha M, Galhardo A, Couto M. Validação da versão portuguesa da Center for Epidemiologic Studies Depression Scale for Children (CES-DC). Revista Portuguesa de Investigação Comportamental e Social 2015; $1: 46-57$.

24. Inderbitzen-Nolan HM, Walters KS. Social aniety scale for adolescents: normative data and further evidence of construct validity. J Clin Child Psychol 2000; 29:360-71.

25. Cunha M, Gouveia JP, Alegre S, Salvador MC. Avaliação da ansiedade social na adolescência: a versão portuguesa da SAS-A. Psychologica 2004; 35:249-63.

26. Soares FC, Lima RA, de Barros MVG, Dahllöf G, Colares V. Development of dental anxiety in schoolchildren: a 2-year prospective study. Community Dent Oral Epidemiol 2017; 45:281-8. 
27. Galland BC, Gray AR, Penno J, Smith C, Lobb C, Taylor RW. Gender differences in sleep hygiene practices and sleep quality in New Zealand adolescents aged 15 to 17 years. Sleep Health 2017; 3:77-83.

28. Zhou H-Q, Shi W-B, Wang X-F, Yao M, Cheng G-Y, Chen P-Y, et al. An epidemiological study of sleep quality in adolescents in South China: a school-based study. Child Care Health Dev 2012; 38:581-7.

29. Guo L, Deng J, He Y, Deng X, Huang J, Huang $G$, et al. Prevalence and correlates of sleep disturbance and depressive symptoms among Chinese adolescents: a cross-sectional survey study. BMJ Open 2014; 4:e005517.

30. Feng J, Cheng W, Rolls ET, Ruan H. Functional connectivities in the brain that mediate the association between depressive problems and sleep quality. JAMA Psychiatry 2018; 75:1052-61.

31. Marinho Saraiva E, Soares Fortunato JM, Gavina C. Oscilações do cortisol na depressão e sono/vigília. Revista Portuguesa de Psicossomática 2005; 7:89-100.

32. Xu Z, Su H, Zou Y, Chen J, Wu J, Chang W. Sleep quality of Chinese adolescents: distribution and its associated factors. J Paediatr Child Health 2012; 48:138-45.

33. Lima RA, Barros MVG, Dos Santos MAM, Machado L, Bezerra J, Soares FC. The synergic relationship between social anxiety, depressive symptoms, poor sleep quality and body fatness in adolescents. J Affect Disord 2020; 260:200-5.

34. Vargas I, Lopez-Duran N. Dissecting the impact of sleep and stress on the cortisol awakening response in young adults. Psychoneuroendocrinology 2014; 40:10-6.

35. Choueiry N, Salamoun T, Jabbour H, El Osta N, Hajj A, Rabbaa Khabbaz L. Insomnia and relationship with anxiety in university students: a cross-sectional designed study. PLoS One 2016; 11:e0149643.
36. Riemann D, Nissen C, Palagini L, Otte A, Perlis ML, Spiegelhalder K. The neurobiology, investigation, and treatment of chronic insomnia. Lancet Neurol 2015; 14:547-58.

37. Owens J; Adolescent Sleep Working Group; Committee on Adolescence. Insufficient sleep in adolescents and young adults: an update on causes and consequences. Pediatrics 2014; 134:e921-32.

38. Liu Y, Peng T, Zhang S, Tang K. The relationship between depression, daytime napping, daytime dysfunction, and snoring in 0.5 million Chinese populations: exploring the effects of socio-economic status and age. BMC Public Health 2018; 18:759.

39. Castro LHCT, Carvalho LBC, Yanaguibashi G, Prado GF. Physically active elderly women sleep more and better than sedentary women. Sleep Med 2008; 9:488-93.

40. Rafie C, Ning Y, Wang A, Gao X, Houlihan R. Impact of physical activity and sleep quality on quality of life of rural residents with and without a history of cancer: findings of the day and night study. Cancer Manag Res 2018; 10:5525-35.

41. Baker FC, Wolfson AR, Lee KA. Association of sociodemographic, lifestyle, and health factors with sleep quality and daytime sleepiness in women: findings from the 2007 National Sleep Foundation "Sleep in America Poll”. J Womens Health (Larchmt) 2009; 18:841-9.

42. Gabryelska A, Sochal M, Wasik B, Bialasiewicz P. Patients with obstructive sleep apnea are over four times more likely to suffer from psoriasis than the general population. J Clin Sleep Med 2018; 14:153.

43. Elder GJ, Wetherell MA, Barclay NL, Ellis JG. The cortisol awakening response - applications and implications for sleep medicine. Sleep Med Rev 2014; 18:215-24. 


\section{Resumo}

O estudo buscou avaliar os fatores associados à qualidade do sono (global e por domínios) entre adolescentes. Foi realizado um estudo transversal com 1.296 estudantes de primeiro ano do ensino médio em escolas públicas na Região Norte do Estado de Pernambuco, Brasil. Foram obtidos dados demográficos, socioeconômicos e comportamentais através de um questionário. A qualidade do sono foi medida com o Pittsburgh Sleep Quality Index (PSQI). O indice de massa corporal (IMC) foi calculado como peso dividido por altura ao quadrado. Os fatores associados à qualidade do sono foram avaliados através da regressão linear multinivel e logística. Observamos que 53\% dos adolescentes relatavam baixa qualidade de sono. Os adolescentes com risco maior de depressão clínica apresentaram 3,45 vezes maior probabilidade de apresentar baixa qualidade de sono (IC95\%: 2,04; 5, 81), e cada unidade adicional na escala de ansiedade social apresentou 1,03 vezes maiores chances (IC95\%: 1,01; 1,05) de baixa qualidade de sono. Os adolescentes com sintomas depressivos mostraram maior latência do sono, maior transtorno do sono e maior disfunção diurna do sono. A ansiedade social mostrou associação com latência do sono, transtorno do sono e disfunção diurna do sono. O risco maior de depressão esteve associado a todos os domínios relacionados à qualidade. Autoavaliação de saúde negativa esteve associada ao transtorno do sono, e inatividade física esteve associada à disfunção diurna do sono. Ansiedade social, e principalmente risco maior de depressão clinica, foram determinantes na baixa qualidade do sono. Mudanças na latência do sono, transtorno do sono e disfunção diurna do sono parecem ser relevantes para a baixa qualidade do sono.

Sono; Depressão; Ansiedade; Adolescente

\section{Resumen}

El objetivo de este estudio fue evaluar factores asociados con la calidad del sueño (general y por ámbitos) en adolescentes. Se realizó un estudio transversal con 1.296 estudiantes del primer año de escuela secundaria, procedentes de escuelas públicas en la Región Norte del Estado de Pernambuco, Brasil. Se obtuvieron datos demográficos, socioeconómicos y comportamentales, a través de un cuestionario. La calidad del sueño se midió usando el Pittsburgh Sleep Quality Index (PSQI). El indice de masa corporal (IMC) se calculó de la ratio de peso y altura al cuadrado. Las regresiones logísticas y lineales multinivel evaluaron factores asociados con calidad del sueño deficiente. Observamos que un $53 \%$ de los adolescentes informaron de una calidad de sueño deficiente. Los adolescentes con mayor riesgo de depresión clínica fueron 3,45 veces más propensos a tener una calidad de sueño deficiente (95\%CI: 2,04; 5, 81), y cada unidad adicional en la puntuación de ansiedad social presentaba 1,03 (95\%CI: 1,01; 1,05) mayores posibilidades de adolescentes sufriendo por calidad de sueño deficiente. Los adolescentes con sintomas depresivos presentaban mayor latencia de sueño, mayores perturbaciones en el sueño, y mayor disfunción durante el día de sueño. La ansiedad social estuvo asociada con la latencia de sueño, perturbaciones de sueño y disfunción del sueño durante el día. Un mayor riesgo de depresión clínica estuvo asociado con todos los ámbitos relacionados con calidad del sueño. Una percepción negativa de salud respecto a la perturbación de sueño e inactividad física estuvo asociada con un sueño deficiente durante el dí. La ansiedad social y, especialmente, un mayor riesgo de depresión clínica fueron determinantes en una escasa calidad de sueño. Los cambios en la latencia del sueño, trastornos del sueño y disfunción del sueño durante el día parecieron relevantes para la deficiente calidad del sueño.

Sueño; Depresión; Ansiedad; Adolescente
Submitted on $15 / \mathrm{Jul} / 2020$

Final version resubmitted on 27/Nov/2020

Approved on 08/Dec/2020 